\title{
Nursing Educators Staff Competences regarding performance in Technical Institute of Nursing
}

\author{
Eman Fathy Ali ${ }^{1}$, Ebtisam Mohammed Abd- ElAal ${ }^{2}$, and Tassier Hamido AboSrea ${ }^{3}$ \\ (1)Nursing Educator in Secondary Technical Nursing School (2) Professor of Community Health \\ Nursing, Faculty of Nursing, Benha University (3) Lecturer of Community Health Nursing, Faculty \\ of Nursing, Benha University.
}

\begin{abstract}
Competence of performance is important in education and the whole generation of nurses. Aim of this study was to assess the nursing educators' staff competence regarding performance in Technical Institute of Nursing. Descriptive research design was utilized. Setting: The study was conducted at Technical Institute of Nursing and Health Technical Institute in Benha City. Two samples were used: Convenient sample for nursing educators' staff [n=38] and simple random sample for students [ $\mathrm{n}=279]$. Three tools were used: (I) A structure questionnaire to assess demographic characteristics of both nursing educators' staff, and students and knowledge of nursing educator staff about competence of performance, (II): Observational checklist to assess their personal and teaching skills and (III): Students' satisfaction questionnaire. Results: $44.7 \%$ of the studied nursing educators staff their age was from 30 to less than 40 years with mean age was $38.08 \pm 9.12,65.8 \%$ of nursing educators staff had good total knowledge scores regarding competence of performance, $55.3 \%$ of them had high level of total observation scores of competence of performance and $46.3 \%$ of students were highly satisfied with nursing educators' staff performance. Conclusion: There were two thirds of nursing educators staff had good total knowledge scores regarding competence of performance, more than half of them staff had high level of total observation scores regarding competence of performance (personal skills and teaching skills) and less than half of students were highly satisfied with nursing educators staff competence of performance. Finally, there was no statistically significant relation between nursing educators staff total knowledge scores and their total observation of performance scores. Recommendation: Continuous up grading of training courses in teaching field to promote competence of performance for nursing educators' staff.
\end{abstract}

Key words: Competence of performance, Nursing educators staff, Technical Institute of Nursing

\section{Introduction}

Nursing Educator Staff (NES) are those who teach students a course of study or practical skills including learning and thinking skills, there are many different ways to teach and help students to learn. Nursing educator staff is an experienced registered nurse who holds a professionally recognized educator education credential and who integrate research-based nursing, management skills, educational knowledge and expertise to achieve learning outcomes that meet the needs of students and other stakeholder in the educational project (Petitte\& Farris, 2020)

Nursing educators' staff plays many roles in educative environment such as teacher role by assume leadership in curriculum, instruction and evaluation. The role involves leadership in several educational contexts: Curriculum development, clinical teaching and supervision, classroom teaching, seminar and virtual teaching. As well, 
application the knowledge of the learning process and management of the learning environment. This role provides the core of education for the other roles of NES. the competences gained through education and experience, are used to engage students in the learning and to broaden the vision of patients, communities and the profession an essential component of the NES role is the ability to model appropriate and desired behaviors of professional practice (Morrison \& Gleddie, 2019).

Competences of performance are must be enable a nursing educator staff to be successful to maximize student learning. Nursing educator staff must have expertise in a wide-ranging array of competencies in an especially complex environment where hundreds of critical decisions are required each day. Few jobs demand the integration of professional judgment and the proficient use of evidence-based competencies as does teaching (Konttila et al., 2019).

Technical Nursing Institute educational program is designed to place students into the workforce upon completion of two-year. The curriculum of Technical Nursing Institute includes a balance of nursing, general studies, and support courses. Nursing students' courses give the opportunity to apply nursing theory and skills either in the simulation laboratories or in clinical settings (Kezar et al., 2019). Technical Nursing Institute environment is the surrounding area of students at institute and the total of all internal and external factors that have an impact on students. Environment includes physical, psychological, social, spiritual and cultural elements. Healthy institute environment is very important for students and staff achievement and to develop attitudes and behaviors that value healthy life style (World Health Organization (WHO), 2019)

\section{Significance of the study}

The total graduates' number of technical institutes of nursing were increased in 2017 compared to 2016 by an increase of $46.4 \%$. The total number of nurses registered in 20162017 is approximately 238,000 but the deficit in nursing professions in governmental hospitals reached to 20\%. Egypt nursing union explained that "there is a plan to eliminate the nursing deficit crisis in Egypt by increasing the number of institutes, colleges of nursing and the number of nursing educators staff at a rate of 25 students per educator according to the regulations of the institute over the next two years so that the crisis will end in 2020 )(Egyptian Central Agency for Public Mobilization and Statistics (ECAPMS), 2017).

Competence of performance among nursing educators play vital step to improve the effectiveness of teaching and learning in nursing, raising educational standers and improve the provision of nursing care and outcomes of health services. Also, develop performance of new nursing generations. So, the aim of this study will be assess the nursing educators' staff competences regarding performance

\section{Aim of the study}

The aim of this study is to assess the nursing educators' staff competences regarding performance in Technical Institute of Nursing.

\section{Research questions:}

1.What is the knowledge of nursing educators' staff about competence of performance?

2. What is competence of performance among nursing educators staff in Technical Institute of Nursing?

3. What are students' satisfactions about nursing educators' staff performance in Technical Institute of Nursing? 
4.Is there relation between knowledge and competence of performance among nursing educators staff?

\section{Subjects and Method}

Research Design: -

A descriptive design was utilized to conduct this study.

\section{Setting: -}

The study was carried out at two Technical Institute of Nursing in Benha City which namely Technical Institute of Nursing and Health Technical Institute.

\section{Sampling: -}

\section{Two samples were used:}

a) Nursing educators staff: Convenient sample.

b) was used to include all nursing educators staff in Technical Institute of Nursing and Health Technical Institute and The total number of sa mple recruited (38) nursing educators staff, wh ere (27) nursing educators staff in Technical In stitute of Nursing and (11) nursing educators st aff in Health Technical Institute.

c) Students: Simple random sample was used in this study and the number of students in the second academic from previous setting year was calculated by using the following equation:

$$
n=\frac{N}{1+N[e]^{2}}
$$

Where ' $\mathrm{n}$ ' was sample size.

' $\mathrm{N}$ ' was total Number of all students presented in previously mentioned. When (430) student from Technical Institute of Nursing and (500) student from Health Technical Institute.

$\mathrm{N}=930$

' $\mathrm{e}$ ' was coefficient factor $=0.05$

Sample size was $=279$

\section{Tool of data collection: -}

Three tools were used in data collection.

Tool I: A structured questionnaire: It was developed by investigator and revised by supervisor staff, based on reviewing related literatures and written in Arabic language, consisted of two parts:
First part [A]: Demographic characteristics of nursing educators' staff. It included 8 questions about [age, residence, sex, qualification, marital status, income, experience years and attending training courses in teaching field].

[B]: Demographic characteristics of nursing students. It included 3 questions about [age, sex, residence].

Second part: It was designed to assess knowledge of nursing educators staff about competence of performance. It was divided two parts.

A-Knowledge of nursing educators' staff regarding competence of performance

B-Knowledge of a nursing educator staff on personal skills to apply competence of performance

\section{Scoring system for knowledge:}

Scoring system is graded according to the items of questionnaire. The scoring system for nursing educators' staff knowledge was calculated as follow [2] score for correct and complete answer, [1] score for correct and incomplete answer and [0] for don't know. For each area of knowledge, the score of the items was summed- up and these score were converted into a percent score. The total knowledge score was 30 point which represents $100 \%$ and categorized into 3 levels as following:

- Good $\rightarrow$ if the score of the total knowledge $>75 \%$ (>22 score).

- Average $\rightarrow$ if the score equal $50 \%$ $70 \%(15-22)$

- Poor $\rightarrow$ if the score $<50 \%(<15)$.

Tool II: Observational checklist: It was adopted by (Rateb, 2013) and was modified by investigator and revised by supervisor staff to assess and observe the nursing educators staff competence of performance. It was divided into two skills: 
1. Personal skills.

2. Teaching skills.

Scoring system for total observational checklist

Each item had three level of answer acceptable, unacceptable and outstanding. These were respectively scored 0,1 and 2 . For each area of observation checklist, the score of the items was summed- up and the total score of nursing educators' staff regarding competence of performance 64 points which represent $100 \%$ and classified into the following:

$\mathrm{High} \rightarrow$ if the score of the total competence of nursing educator $>75 \%$ ( $>48$ score).

Moderate $\rightarrow$ if the score equals $50-75 \%$ (32- 48 score).

Low $\rightarrow$ if the score $<50 \%$ ( $<32$ score).

Tool III: Students satisfaction questionnaire: It was adopted by Abo ElSaud and Mahmoud, (2018) and was modified by investigator and revised by supervisor staff to assess students' satisfaction about the educators nursing staff competence of performance. It was divided into two sectors:

1] Nursing educators' staff communication with student.

2] Nursing educators staff performance

\section{Scoring system:}

Scoring system for total observation checklist

Each item had three level of answer Always, Sometimes and Never. These were respectively scored 2, 1 and 0 . For each area of questionnaire, the score of the questions was summed- up and the total score of students' satisfaction regarding nursing educators' staff competence of performance 30 points which represent $100 \%$ and classified into the following:

- Highly satisfied $\rightarrow$ if the score of students' satisfaction $>75 \%$ ( $>22$ score).

- Satisfied $\rightarrow$ if the score equals $50-75 \%$ (22- 15score).

- Unsatisfied $\rightarrow$ if the score $<50 \%(<15$ score).

\section{Content validity:}

The validity of data collection tools was tested by 3 experts of Faculty Nursing Staff from the Community Health Nursing Specialists who reviewed the tool for clarity, relevance, comprehensiveness, applicability, easiness for implementation and all recommended modifications were carried out.

\section{Reliability of tools:}

The reliability of tools was applied by the investigator for testing the internal consistency of the tools. The tools reliability was measured by using Cronbach's Alpha for knowledge of nursing educator staff about competence of performance was 0.95 , for observation checklist regarding nursing educator competence of performance was 0.94 and for student satisfaction regarding nursing educator competence of performance was 0.94 .

\section{Operational design: \\ Preparatory phase:}

Extensive review of the recent and past available national and international references related to the research was made by using magazine, text books, articles and internet search. This was necessary for the investigator to be acquainted with and oriented about aspects of the research problem as well as assist in the development of the data collection tools.

\section{Ethical consideration:}

All ethical issues were assured; Oral consent has been obtained from participants before conducting the interview and the participants were given a brief orientation of the purpose of the study. Participants were also assured that all information gathered 
would be treated confidentially and used only for the purpose of the study. Participants had the right to withdraw from the study at any time without giving any reasons.

\section{Pilot study:}

The pilot study was carried out on $10 \%$ of educators' staff [4] and students [28] from total sample of nursing. The pilot study was made to assess the tools clarity, applicability and time needed to fill each sheet as well as to identify any possible obstacles that may hinder the data collection. No modification was done so the sample was included in the study.

Field work:

Data were collected from the end of January 2020 to the middle of March 2020; the study was conducted by the investigator for the studied sample in selected setting at Technical Institute of Nursing and Health Technical Institute at Benha city. The investigator visited each setting from $9.00 \mathrm{am}$ to $1.30 \mathrm{pm}, 3$ days /week [Saturday, Monday and Tuesday] to meet all nursing educators' staff and student according to the time of lecture the average number was between 1-2 nursing educator staff/ day $[\mathrm{n}=38]$ and 12-15 student/ day $[n=279]$. The investigator explained the purpose and importance of the study to participants and obtained their consent. The time consumed to full demographic sheet and knowledge sheet [tool I] by nursing educators staff around 30 minutes, the time consumed to fill the observational checklist sheet [tool II] around 45mintues and the time consumed to fill demographic sheet and students' satisfaction sheet [tool III] by student's average 15 minutes.

\section{Administrative design:}

An official letter was obtained and delivered from the Dean of the Faculty of Nursing Benha University directed to
Manager of Technical Institute of Nursing and Health Technical Institute at Benha city where the study was conducted, the title, objectives, tools and study technique had been explained to gain their approval to conduct the study.

\section{Statistical design:}

The collected data was analyzed, organized and tabulated with using the Statistical Package for Social Sciences [SPSS version 20], which was used frequencies and percentage for qualitative descriptive data, $\mathrm{x}^{2}$ was used for relation tests, mean and standard deviation was used for quantitative data.

Significance level was considered as follows:

\section{Highly statistically significant}

$$
\mathrm{P}<0.001 * *
$$

\section{Statistically significant}

$$
\mathrm{P}<0.05^{*}
$$

\section{Not significant}

$$
\mathrm{P}>0.05
$$

\section{Results}

Table (1) shows that $44.7 \%$ the studied nursing educator staff their age ranged from 30 less than 40 years with mean \pm SD $38.08 \pm 9.12,55.3 \%$ of them lived in rural areas while $81.6 \%$ of them were female, $50 \%$ of them had master degree,78.9\% of them were married and $57.9 \%$ of them had sufficient income and $42.1 \%$ of them had experience years from 5 to 10 years.

Table (2) reveals that $44.8 \%$ of the studied students their age were 20 years with mean age were $19.22 \pm 0.88,88.2 \%$ of them were female and $72.4 \%$ of them lived in rural areas.

Table (3) illustrates that $81.6 \%$ of the studied nursing educators' staff had complete and correct knowledge regarding performance of an efficient nursing educators' staff in facilitating the learning process, $55.3 \%$ of them had incomplete knowledge regarding concept of competence performance and 
$10.5 \%$ of them don't know stages of competence performance.

Figure (1) illustrates that $65.8 \%$ of nursing educators' staff had good total knowledge score regarding competence of performance, while $18.4 \%$ of them had poor total knowledge score regarding competence of performance.

Figure (2) describes that $55.3 \%$ of the studied nursing educators' staff had highly level of total observational scores of competence of performance and $7.9 \%$ of them had low level of total observation scores regarding competence of performance.

Figure (3) illustrates that $46.3 \%$ of students were highly satisfied regarding nursing educator staff performance, only $24 \%$ of students were un satisfied on nursing educator staff performance.

Table (4) shows that there was statistically significant relation between total knowledge score and total competence of performance score of nursing educator staff. 
Table (1) Distribution of the studied nursing educators staff regarding their demographic characteristics $[\mathrm{n}=38]$.

\begin{tabular}{|c|c|c|}
\hline Demographic characteristics & No. & $\%$ \\
\hline \multicolumn{3}{|l|}{ Age } \\
\hline$<30$ & 9 & 23.7 \\
\hline $30-<40$ & 17 & 44.7 \\
\hline $40+$ & 12 & 31.6 \\
\hline \multicolumn{3}{|l|}{ Mean \pm SD $38.08 \pm 9.12$} \\
\hline \multicolumn{3}{|l|}{ Residence } \\
\hline Rural & 21 & 55.3 \\
\hline Urban & 17 & 44.7 \\
\hline \multicolumn{3}{|l|}{ Sex } \\
\hline Male & 7 & 18.4 \\
\hline Female & 31 & 81.6 \\
\hline \multicolumn{3}{|l|}{ Qualification } \\
\hline Bachelor & 3 & 7.9 \\
\hline Master degree & 19 & 50.0 \\
\hline Doctorate degree & 16 & 42.1 \\
\hline \multicolumn{3}{|l|}{ Marital status } \\
\hline Single & 2 & 5.3 \\
\hline Married & 30 & 78.9 \\
\hline Widow & 4 & 10.5 \\
\hline Divorced & 2 & 5.3 \\
\hline \multicolumn{3}{|l|}{ Income } \\
\hline Insufficient & 11 & 28.9 \\
\hline Sufficient & 22 & 57.9 \\
\hline Sufficient and save & 5 & 13.2 \\
\hline \multicolumn{3}{|l|}{ Experience years } \\
\hline$>5$ years & 1 & 2.6 \\
\hline $5-10$ years & 16 & 42.1 \\
\hline $11-15$ years & 10 & 26.3 \\
\hline Up to 16 years & 11 & 28.9 \\
\hline
\end{tabular}

Table [2] Distribution of the studied students regarding their demographic characteristics [ $\mathrm{n}=279]$.

\begin{tabular}{lll}
\hline Demographic characteristic of the students. & No & \% \\
\hline Age + & 77 & 27.6 \\
$18-$ & 70 & 25.1 \\
$19-$ & 125 & 44.8 \\
$20-$ & 7 & 2.5 \\
$21-$ & & \\
Mean \pm SD19.22 \pm 0.88 & & \\
Sex & 33 & 11.8. \\
Male & 246 & 88.2 \\
Female & & \\
Residence & 202 & 72.4 \\
Rural & 77 & 27.6 \\
Urban & & \\
\hline
\end{tabular}




\section{Nursing Educators Staff Competences regarding performance in Technical Institute of nursing}

Table [3] Distribution of the studied nursing educators' staff knowledge regarding competence of performance $[\mathrm{n}=38]$.

\begin{tabular}{|c|c|c|c|c|c|c|}
\hline \multirow[t]{2}{*}{ Knowledge about competence of performance } & \multicolumn{2}{|c|}{$\begin{array}{l}\text { Correct and } \\
\text { complete }\end{array}$} & \multicolumn{2}{|c|}{$\begin{array}{l}\text { Correct and } \\
\text { incomplete }\end{array}$} & \multicolumn{2}{|c|}{ Don't know } \\
\hline & No. & $\%$ & No. & $\%$ & No. & $\%$ \\
\hline Concept of competence of performance & 17 & 44.7 & 21 & 55.3 & 0 & 0.0 \\
\hline Types of competence of performance & 26 & 68.4 & 12 & 31.6 & 0 & 0.0 \\
\hline Factors affecting competence of performance & 27 & 71.1 & 9 & 23.7 & 2 & 5.3 \\
\hline Component of competence of performance & 27 & 71.1 & 9 & 23.7 & 2 & 5.3 \\
\hline Stages of competence of performance & 23 & 60.5 & 11 & 28.9 & 4 & 10.5 \\
\hline Importance of competence of performance & 22 & 57.9 & 13 & 34.2 & 3 & 7.9 \\
\hline Characteristics of competence of performance & 23 & 60.5 & 12 & 31.6 & 3 & 7.9 \\
\hline $\begin{array}{l}\text { Personal characteristics of a qualified nursing educator } \\
\text { staff }\end{array}$ & 30 & 78.9 & 7 & 18.4 & 1 & 2.6 \\
\hline Skillful qualities of a qualified nursing educator staff & 30 & 78.9 & 7 & 18.4 & 1 & 2.6 \\
\hline $\begin{array}{l}\text { Professional qualities of a qualified nursing educator } \\
\text { staff }\end{array}$ & 29 & 76.3 & 8 & 21.1 & 1 & 2.6 \\
\hline $\begin{array}{l}\text { Benefits of nursing educator staff competence of } \\
\text { performance }\end{array}$ & 30 & 78.9 & 7 & 18.4 & 1 & 2.6 \\
\hline $\begin{array}{l}\text { Performance of an efficient nursing educator staff in } \\
\text { facilitating the learning process }\end{array}$ & 31 & 81.6 & 6 & 15.8 & 1 & 2.6 \\
\hline $\begin{array}{l}\text { Performance of an efficient nursing educator staff in } \\
\text { curriculum design }\end{array}$ & 30 & 78.9 & 7 & 18.4 & 1 & 2.6 \\
\hline Evaluation of nursing educator staff competence & 26 & 68.4 & 9 & 23.7 & 3 & 7.9 \\
\hline Benefit of evaluating nursing educator staff competence & 27 & 71.1 & 8 & 21.1 & 3 & 7.9 \\
\hline
\end{tabular}

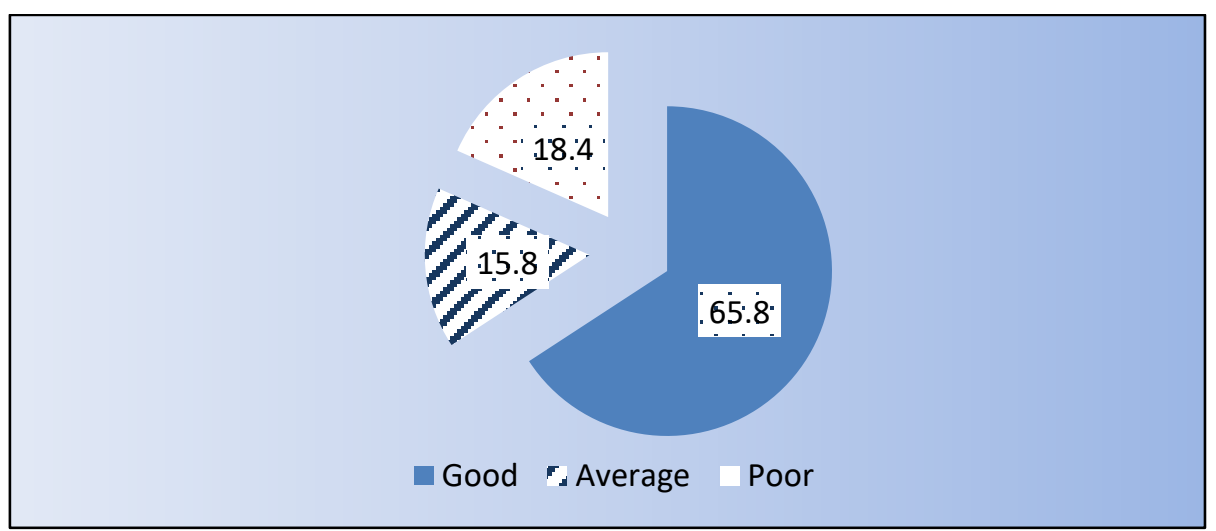

Fig [1] Percentage distribution of the studied nursing educators' staffs' total knowledge score regarding competence of performance $[n=38]$. 


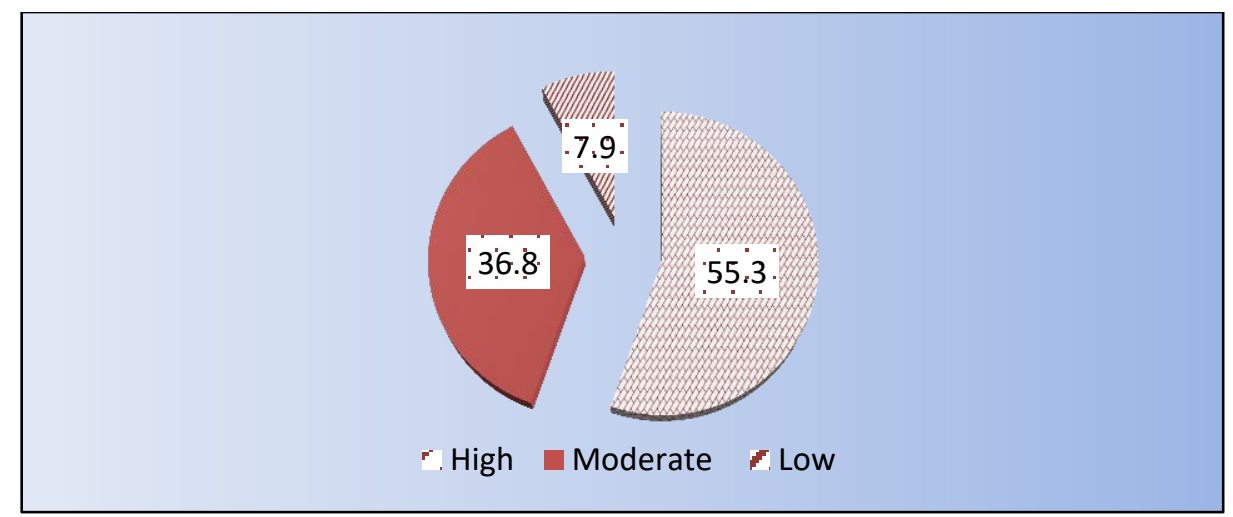

Fig [2] Percentage distribution of the studied nursing educators' staffs' regarding total observation scores regarding their competence of performance $[n=38]$.

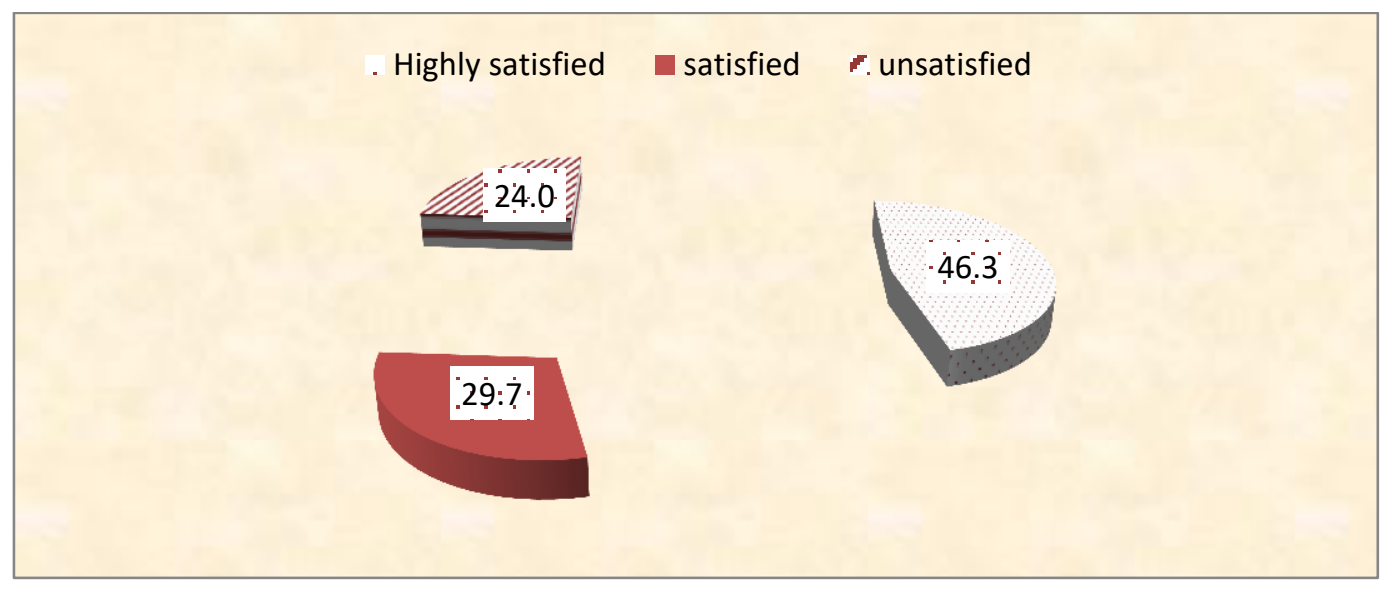

Figure [3]: Percentage distribution of studied students regarding their satisfaction regarding nursing educator staff competence of performance [ $n=279]$.

Table [4] Relation between total knowledge score and total competence of performance score of nursing educator staff $[\mathrm{n}=38]$

\begin{tabular}{|c|c|c|c|c|c|c|c|c|}
\hline \multirow{3}{*}{$\begin{array}{l}\text { Total competence of } \\
\text { performance score }\end{array}$} & \multicolumn{8}{|c|}{ Total Knowledge score } \\
\hline & \multicolumn{2}{|c|}{$\begin{array}{l}\text { Poor } \\
{[n=7]}\end{array}$} & \multicolumn{2}{|c|}{$\begin{array}{l}\text { Average } \\
{[n=6]}\end{array}$} & \multicolumn{2}{|c|}{ Good $[n=25]$} & \multirow[t]{2}{*}{$\mathbf{X}^{2}$} & \multirow[t]{2}{*}{$\begin{array}{l}p- \\
\text { value }\end{array}$} \\
\hline & No & $\%$ & No & $\%$ & No & $\%$ & & \\
\hline Low $[n=6]$ & 1 & $\begin{array}{l}14 . \\
3\end{array}$ & 0 & 0.0 & 2 & 8.0 & 3.946 & 0.413 \\
\hline Moderate [n=14] & 3 & $\begin{array}{l}42 . \\
9\end{array}$ & 4 & 66.7 & 7 & 28.0 & & \\
\hline High $[n=21]$ & 3 & $\begin{array}{l}42 . \\
9\end{array}$ & 2 & 33.3 & 16 & 64.0 & & \\
\hline
\end{tabular}




\section{Discussion}

Competence of performance is quality of being adequately or well qualified to perform a task. A person gain competence through education, training and experience. Competence of performance is observable or measurable skills, knowledge and attitude Day, (2017). Nursing educators' staff is responsible for designing, delivering, evaluating and revision academic and continuing education programs for student, as well, preparing lectures to students, supervising student's class work, laboratory and clinical work and evaluating the students [Saini \&Kaur, 2018].

According to nursing educators' staff demographic characteristics, this study showed that less than half of the studied nursing educator staff their age was from 30 less than 40 years with mean age was $38.08 \pm 9$, majority of them were female [table 1]. These findings agreed with Panlican et al., (2018) who studied the students and teachers' perception of an effective clinical nurse teacher characteristics: A comparative study in Australia nurse teacher [ $\mathrm{N}=46]$, who found that half of the participating teachers belong to the middle age group and the majority of the participating teachers were female. However, these findings disagreed with Bifftu et al. (2018), who study was about the Effective clinical teaching behaviors views of nursing students and nurse educators in Northwest Ethiopia, nurse educators $[\mathrm{N}=40]$, who reported that two thirds of nurse educator were male and nearly half of them more than 40 years.

Regarding to residence of nursing educators staff, more than half of them lived in rural area, half of them had master degree, more than three quarter of them were married, according to income per month approximately three fifths of them had sufficient income per month and more than two fifths of them had experience years from 5 to 10 years.

As regard attended training courses in teaching field, the most of nursing educators' staff attended training courses on teaching method of performance for nursing educators. This finding disagreed with the study conducted by Mallek \& El-Hosany, (2020) who study was about the Training program for improving clinical teaching knowledge as a competence of clinical instructors in Egypt $[\mathrm{N}=43]$ who reported that the majority of clinical instructors did not attain any training program. This might be due to promote competence of performance for nursing educators' staff.

According to the demographic characteristics of the students, the present study revealed that more than two fifths of the studied students their age was twenty years and the majority of them were females [table 2]. These findings with agreed with Panlican et al. (2020), students $[\mathrm{N}=244]$ who reported that the most of nursing students were females and their age was twenty years. Conversely, these findings disagreed with Bifftu et al. (2018), student [ $\mathrm{N}=178]$, who reported that slightly more than three fifth of student were male and their age more than twenty years. This might due to nursing job is female profession.

According to nursing educators' staff knowledge regarding competence of performance, the current study illustrated that the majority of the studied nursing educators' staff had correct and complete answer about knowledge regarding performance of an efficient nursing educator staff in facilitating the learning process [table 3]. This finding was congruent with Hof (2020), who study was about what is the policy about my Role? Review of core plans for nurse educators in Israel $[\mathrm{N}=100]$, who reported that majority of nurse educator staff had knowledge regarding 
performance of an efficient nurse educator in facilitating the learning. This might be due to the nursing educators staff attended training courses in teaching field.

According to nursing educators' staff total knowledge scores regarding competence of performance, the present study clarified that two thirds of nursing educators' staff had good total knowledge score regarding competence of performance [figure 1]. This finding agreed with the study conducted byMallek \& El-Hosany (2020), who reported that two thirds of clinical instructors had good knowledge regarding competence of performance Conversely, this finding was inconsistent with the study carried out by Atiea et al. (2017), who study was about the Intervention program for clinical instructors about clinical teaching in Egypt [N=40] who found that all the participants had poor knowledge regarding competence of performance. This might be due to the half of nursing educators staff had master degree.

Regarding to nursing educators' staff regarding total observation scores regarding competence of performance, the result of this study appeared that, more than half of nursing educators had highly level of total observation scores regarding competence of performance [figure 2]. This finding of agreed with the study carried out by Amhag et al. (2019), who studied the Nurse educators' use of digital tools and needs for digital competence in higher education in Sweden [ $\mathrm{N}=405]$, who reported that, more than half of nurse educator had highly level of observation regarding competence of performance. On the other hand, this finding disagreed with Rateb et al. (2013) who studied the Assessment the quality of nursing teacher performance in Egypt [N=92], and reported that, nursing teacher had high percent of good observation regarding competence of performance. This might be due the nursing educators staff had good knowledge regarding competence of performance and had master degree of nursing.

Concerning to students regarding their satisfaction about nursing educator staff competence of performance. The current study revealed that, less than half of students were highly satisfied regarding nursing educator competence of performance [figure3]. This result supported by Nejad et al. (2019), who studied "The investigation of nursing student satisfaction with the first clinical education in Iran" $(\mathrm{N}=390)$ and reported that less than half of students were highly satisfied with nursing educator competence of performance. According to Papastavrou et al. (2016), who studied the "Nursing students' satisfaction of the clinical learning environment in Cyprus" $(\mathrm{N}=463)$ and reported that the majority of nursing students were highly satisfied with nursing educator competence of performance. This might be due to nursing educators staff were keen to introduce the subject in an interesting way, treats the student fairly and equally and focus on students' feedback that gives the students more confidence.

Regarding to relation between total knowledge scores and total competence performance scores of nursing educator staff. The finding of the current study revealed that there was no statistically significant relation between total knowledge sores and total competence of performance scores [table 10]. This finding disagreed with the study conducted in by Said et al. (2018), who studied the Assessment of nursing instructors clinical teaching competences level of performance and knowledge in Egypt [ $\mathrm{N}=65]$, who reported that were statistically significant relation between nursing instructors clinical teaching competences level of performance and knowledge.

\section{JNSBU}




\section{Conclusion}

Based on the results of the present study and research questions, the study concluded that:

There were two thirds of nursing educators staff had good total knowledge scores regarding competence of performance. More than half of nursing educators' staff had high level of total observation scores regarding competence of performance (personal skills and teaching skills). Less than half of students were highly satisfied regarding nursing educator staff performance. Finally, there was no statistically significant relation between total knowledge scores and total observation of competence of performance scores.

\section{Recommendation}

In the light of the result of the present study, the following recommendations are suggested:

- Continuous up grading of courses in teaching field to promote competence of performance for nursing educators' staff.

- Continuous assessment of nursing educators staff learning skills and monitoring their competence of performance.

- Provide new technology toward learning process in technical nursing institutes.

- Further studies to study the factors that affecting on competence of performance.

\section{Reference}

- Amhag, L., Hellström, L. and Stigmar, M. (2019). Teacher educators' use of digital tools and needs for digital competence in higher education. Journal of digital learning in teacher education; 35(4): 203-220

- Atiea, K., Elsayed, N. and Abdeen, M. (2017). Intervention program for clinical instructors about clinical teaching. Zagazig nursing journal; 13(1): 199-212.

- Bifftu, B., Dachew, B., Tiruneh, B., Ashenafie, T., Tegegne, E. and Worku, W. (2018). Effective clinical teaching behaviors views of nursing students and nurse educators at University of Gondar, Northwest Ethiopia: Cross-sectional institution based study. Journal of caring sciences; 7(3): 119.

- Day, C. (2017). Competence-based education and teacher professional development. In competence-based vocational and professional education. Doctorate thesis, Akershus University College of Applied Sciences. Pp. 165-182. Springer, Cham.

- Egyptian Central Agency for Public Mobilization and Statistics (ECAPMS), (2017). Report of nursing educators staff in Egypt. Available at http//www.capms.eg.com-/2017. Accessed on 5 November 2019.

- Experience in Universities of Medical Sciences in Iran. Journal of Medicine and Life; 12(1): 75

- Hof, Y. (2020). what is the policy about my role? Review of core plans for nurse educators in the world. Journal of US-China Public Administration; 17(3): 120-123.

- Kezar, L., Kirschner, K., Clinchot, D., Laird-Metke, E., Zazove, P., and Curry, R. (2019). Leading practices and future directions for technical standards in medical education. Journal of Academic Medicine; 94(4): 520-527.

- Konttila, J., Siira, H., Kyngäs, H., Lahtinen, M., Elo, S., Kääriäinen, M., and Utsumi, M. (2019). Healthcare professionals' competence in digitalisation: A systematic review. Journal of clinical nursing; 28(6): 745-761

- Mallek, S. S. and El-Hosany, W. A. E. A. (2020). Training program for improving 
clinical teaching knowledge as a competence of clinical instructors. American Journal of Nursing; 8(3): 379-391.

- Morrison, H. and Gleddie, D. (2019). Playing on the same team: Collaboration between teachers and educational assistants for inclusive physical education. Journal of Physical Education, Recreation \& Dance; 90(8): 34-41.

- Nejad, F., Asadizaker, M., Baraz, S. and Panlican, A., Al Saqri, S., Raguindin, S., Villacorte, L. and Pangket, P. (2020). Students and teachers' perception of an effective clinical nurse teacher characteristic: A comparative study. Journal of Nursing Education and Practice; 10(11): 15-22.

- Papastavrou, E., Dimitriadou, M., Tsangari, H. and Andreou, C. (2016). Nursing students' satisfaction of the clinical learning environment: A research study. BMC nursing journal; 15(1): 44

- Petitte, D. and Farris, C. (2020). Using gaming as active teaching strategy in nursing education. Teaching and Learning in nursing journal; 15(1): 61-65.

- Rateb, M., El-shehali, H., and Abed Elwahab, E. (2013). Assessment the quality of Nursing Teachers performance in technical nursing schools. Master this in Ismailia versus Suez city, Suez Canal University, faculty of nursing.50-60.

- Said, Z., Shaban, F., Ghadery, S. H., \& Elmelegy, O. E. A. (2018). Clinical Teaching Competences of Nursing Demonstrators at Faculty of Nursing Post Intervention program. Tanta Scientific Nursing Journal; 14(2): 32-55.

- Saini, R. and Kaur, S. (2018). Exploring the job-tasks of nursing teachers in India: A Qualitative study. International journal of Nursing Education and Research; 6(1): 5-11
- World Health Organization (WHO). (2017). Nurse educator core competencies Availablehttps://www.who.int/hrh/nursing midwifery/nurse_educator050416.pdf. Accessed on 17july 2020, 10:12pm.

- World Health Organization [WHO] 2018) Nurse Educator core competencies, vol.70, pp.420-435, 2018. 
الترقيم الدولمي:3934 - 2682

مجلّة العلوم التمريضية - جامعة بنها

الملخص العربيى

كفاعات أعضاء هيئة التدريس المتعلقه بالأداء فى المعاهد القتية للتمريض

إيمان فتحي علي - ابتسام محمد عبد العال- تيسير حميدو أبو سريع

تمكن كفاءات أعضاء هيئة التدريس من الوصول الى الحد الأقصى من النجاح في تعليم الطلاب حيث تساعد كفاءة الأداء لعضو هيئة التدريس بأن يصبح محترف في العملية التعليمية وتمكينهم من تنظيم العملية التعليمية. لذلك هدفت الدراسة إلى تقييم كفاءات أعضاء هيئة التدريس المتعلقه بالأداء فى المعاهد الفنية للتمريض فى ددينة بنها. وقد أجريت الدراسة فى المعهد الفنى الصحى و المعهد الفنى للتمريض على یی من أعضاء هيئة التدريس وrV9 طالب. حيث كشفت النتائج أن أعضاء هيئة التدريس لديهم معلومات جيدة فيما يتعلق بكفاءة الأداء ولديهم مستوى عالٍ في كفاءة الأداء وأن الطلاب لديهم رضا عن مستوى أداء أعضاء هيئة التدريس. كما أوصت الدراسة بأهمية التطوير المستمرللدورات التدريبية في المجال التدريسي لرفع كفاءة الأداء لدى

أعضاء هيئة التدريس.

JNSBU

48 